\title{
Acil Serviste Akut Apandisit Tanısı Almış Çocuklarda Trombosit Kütle İndeksi ve Diğer Hemogram Parametrelerinin Tanısal Değeri
}

\section{Diagnostic Value of Platelet Mass Index and Other Hemogram Parameters in Children Diagnosed with Acute Appendicitis in The Emergency Department}

\author{
Eyyup Sabri SEYHANLI ${ }^{1}$
}

1 Sağlık Bilimleri Üniversitesi, Şanlıurfa Mehmet Akif İnan SUAM, Acil Servis Kliniği, Şanlıurfa, Türkiye

Öz.

Amaç: Akut apandisit, acil servise karın ağrısı şikâyeti ile başvuran hastalarda en sık karşılaşılan acil cerrahi patolojilerden biridir. Akut apandisit tanısı konulan hastalarda morbidite ve mortaliteyi en aza indirmek için hızı ı ve doğru tanı koymak gereklidir. Hemogram parametreleri akut apandisit tanısında önemlidir. Biz bu çalışmada akut apandisit tanısı konulup ameliyat edilen hastaların acil serviste bakılan hemogram parametrelerini inceleyerek histopatolojik tanıdaki yerini araştırmayı amaçladık. Materyal ve metod: Ocak 2018-Haziran 2020 tarihleri arasında SBÜ Ş.Urfa Mehmet Akif Inan SUAM hastanesi acil servisine karın ağrısı şikayetiyle başvuran ve akut apandisit ön tanısıyla ameliyat edilen 116 hastanın acil servise başvurusundaki hemogram parametreleri ve cerrahi sonrası patoloji sonuçları geriye dönük incelendi. Patoloji sonuçlarına göre hastalar üç gruba ayrıldı ve hemogram parametreleri ile akut apandisit arasında bir ilişki olup olmadığına bakıldı.

Bulgular: Apendektomi yapılan 116 hastanın yaş ortalaması 12.0 (9.0-15.0) olup \%60,3'ü $(n=70)$ erkek ve \%39,7 (n=46)'u kadın idi. Cerrahi öncesi hastaların \%76,7 ( $\mathrm{n}=89)^{\prime}$ ine batın Ultrasonografi (USG), \%18,1 $(\mathrm{n}=21)^{\prime}$ ine batın Bilgisayarlı Tomografi (BT) ve \%5,2 (n=6)'sine de hem batın USG hem de batın BT görüntülemesi yapıldı. Cerrahi sonrası yapılan patolojik inceleme sonrası hastaların \%11,2 ( $n=13$ )'inde normal apendiks, \%70,1 $(n=82)$ 'inde basit inflame apandisit, \%18,7 ( $n=21)$ 'de ise Komplike (flegmenöz, gangrenöz, perfore) apandisit bulgularına rastlandı. Patoloji sonucu akut apandisit olmayan ile akut apandisit olan hastaların hemogram parametreleri karşılaştıııldı. Nötrofil/Lenfosit oranı (NLO) ile aralarında istatistiksel olarak anlamlı fark bulundu ( $p<0.05)$. Kırmızı kan hücresi genişliği (RDW), Trombosit kütle indeksi (TKi), Beyaz kan hücresi (WBC), Nötrofil sayısı ile aralarında istatistiksel olarak anlamlı fark bulunmadı ( $p>0.05)$.

Sonuç: Akut apandisit tanısında kullanılabilen WBC, Nötrofil sayısı, NLO, RDW, TKI, kolay ulaşılabilen ve hızı değerlendirilen hemogram parametrelerindendir. Fakat bu parametreler tek başına akut apandisit tanısını koymakta yeterli değildir. Zamanında ve doğru tanı koyabilmek için iyi bir anamnez, fizik muayene ve uygun radyolojik görüntüleme tetkiklerinin yapılması gerekmektedir.

Anahtar Kelimeler: Acil servis, Trombosit kütle indeksi, Hemogram parametreleri, Akut apandisit

Abstract

Background: Acute appendicitis (AA) is one of the most common emergency surgical pathologies in patients presenting to emergency department. with abdominal pain. In patients diagnosed with Acute appendicitis, rapid and accurate diagnosis is necessary to reduce morbidity and mortality. Hemogram parameters are important in diagnosis of acute appendicitis. In this study, we aimed to investigate the place of acute appendicitis, in histopathological diagnosis by examining the hemogram parameters of the patients who were first examined in the emergency department.

Materials and Methods: Hemogram parameters and postoperative pathology results of 116 patients who presented with abdominal pain to the Emergency Department of SBÜ Ş.Urfa Mehmet Akif Inan SUAM hospital between January 2018 and June 2020 and operated with the preliminary diagnosis of acute appendicitis were analyzed retrospectively. Patients were divided into three groups according to their pathology results and were questioned whether there was a relationship between hemogram parameters and acute appendicitis.

Results: Of the 116 patients who underwent appendectomy, the average age was 12.0 (9.0-15.0), of which $60.3 \%(\mathrm{~N}=70)$ were male and $39.7 \%(n=46)$ were female. In the study, there were $60.3 \%(n=70)$ male patients and $39.7 \%(n=46)$ female patients. Abdominal Ultrasonography (USG) was performed to $76.7 \%(n=89)$ patients and abdominal Computed Tomography (CT) was performed to $18.1 \%(n=21)$ the patients before surgery. Both USG and abdominal CT were performed in $5.2 \%(n=6)$ patients. After postoperative pathological analysis, $11.2 \%(n=13)$ of the patients had normal appendix, $70.1 \%(n=82)$ of the patients had simple inflamed appendicitis, $18.7 \%(\mathrm{n}=21)$ of the patients had Complicated (phlegmenous, gangrenous, perforated) appendicitis. Hemogram parameters of non- acute appendicitis and acute appendicitis patients were compared. There was statistically significant difference between Neutrophil/lymphocyte ratio (NLR) $(p<0.05)$. There was no statistically significant difference between Red blood cell width (RDW), Platelet mass index (PMI), White blood cells (WBC), neutrophil count ( $p>0.05)$. Conclusion: White blood cells (WBC), neutrophil count, NLR, RDW, PMI, are easily accessible and fast assessable hemogram parameters, available for diagnosis of acute appendicitis patients. However, these parameters alone are not enough for diagnosis of acute appendicitis. A good anamnesis, physical examination and appropriate radiologic imaging studies are needed to make a timely and accurate diagnosis.

Key words: Emergency Department, Platelet Mass Index, Hemogram Parameters, Acute Appendicitis

\section{Sorumlu Yazar I \\ Corresponding Author}

Dr. Öğr. Üyesi Eyyup Sabri
ŞEYHANLI

Sağlık Bilimleri Üniversitesi, Şanlıurfa Mehmet Akif İnan SUAM, Acil Servis Kliniği, Şanlıurfa, Türkiye

e-mail: eyyup-1976@windowslive.com Tel: +90 (506) 8157998

Geliş tarihi / Received: 09.10 .2020

Kabul tarihi / Accepted: 04.12 .2020

DOI: $10.35440 /$ hutfd. 808427 


\section{Giriş}

Karın ağrısı nedeniyle acil servise başvuran hasta grubunda en sık görülen tanılardan biri akut apandisittir (AA) (1). Görülme insidansı yılda 11/10.000 olup erkeklerde kadınlardan yaklaşık üç kat daha fazla görülen AA günümüzde özellikle çocuk yaş grubu olmak üzere tüm yaş gruplarında karın ağrısına neden olan patolojilerden akut batın nedenleri arasında ilk sıralarda olduğu bilinmektedir (2-4). AA tanısı geç konulduğunda mortalitesi oldukça yüksek olduğu ve çocuklarda geç tanı oranının da \%30-65, tüm yaş gruplarında mortalite oranı ise $\% 0,3$ olduğu kabul edilmektedir $(4,5)$.

AA tanısı; anamnez, fizik muayene, klinik belirtilere, laboratuvar bulgularına, görüntüleme veya skorlama sistemlerine göre belirlenir ancak özellikle küçük çocuklarda güvenilir bir öykü ve klinik muayene zor olduğundan dolayı hiçbiri yalnız başına kesin bir tanı yöntemi değildir $(6,7)$. Son yıllarda daha sık kullanılmaya başlanılan ultrasonografi (USG) ve/veya bilgisayarlı tomografi (BT) görüntülemelerine rağmen apendektomi yapılan hastaların \%20-30 civarında apandisit olmadığı görülmüştür $(8,9)$. AA vakalarının $\% 50$ 'sinde göbek çevresinde görülen karın ağrısı ve ardından ağrının sağ alt kadrana göçü ve beraberinde kusma görülür, Karın ağrısıyla beraber bulantı, kusma, iştahsızlık ve kandaki bazı parametrelerindeki yükseklik ön tanıda kullanılan kriterler arasındadır ancak özellikle farklı anatomik yerleşimli hastalarda atipik bulgulara daha sık rastlanmaktadır (2).

AA'te geç tanı konulması nedeniyle oluşabilecek komplikasyonların sonucu olarak gelişebilen morbidite ve mortaliteyi düşürmek amacıyla yeni çalışmalara intiyaç duyulmaktadır. Akut inflamasyon belirteçlerinden C-reaktif protein (CRP), nötrofil, lenfosit değerlerinin AA ile ilişkisinin olduğunu belirten bazı literatür bilgileri vardır (8). Bizim çaıışmamızda AA ön tanısı ile yatışı yapılarak apendektomi yapılmış hastaların acil servise başvurduğu sırada yapımış ilk tam kan sayımı değerlerini inceleyerek ortalama trombosit hacmi (MPV) ile Trombosit sayısının çarpımı sonucu hesaplanan trombosit kütle indeksi (TKI) ve diğer hemogram parametrelerinin tanıdaki yerini araştırmayı amaçladık (10).

\section{Materyal ve Metod}

Çalışma yılda 350-400 bin civarında hasta başvurusu olan üçüncü basamak Sağlık Bilimleri Üniversitesi Ş.Urfa Mehmet Akif İnan SUAM acil servisindeki kayıt altına alınmış biyokimyasal belirteçler retrospektif olarak incelendi. Ocak 2018-Haziran 2020 tarih aralığında acil servise başvurmuş ve $A A$ ön tanısı ile apendektomi yapılmış çocuk hastaların acil servis kliniğindeki ilk başvuru hemogram belirteçleri, batın USG, BT sonuçları ve apendektomi sonrası yapılan histopatolojik sonuçları incelendi. Çalışmamıza 18 yaş ve altındaki çocuk hastalar alındı. Apendektomi sonrası histo- patolojik sonuçları olmayan, AA ön tanısıyla hastaneye yatırıldıktan sonra apendektomi yapılmayan, bilinen hematolojik hastalığı olanlar, immunsupresif tedavi alanların verileri çalışmaya alınmadı. Hastalar apendektomi sonrası histopatolojik sonuçlarına göre;

Grup A: normal apendiks dokusu,

Grup B: akut basit inflamasyon görülen apandisit dokusu, Grup C: Komplike (flegmenöz, gangrenöz, perfore) akut apandisit dokusu içeren gruplar olmak üzere 3'e ayrıldı ve hemogram belirteçlerinin ortalamaları analiz edildi. Hastaların bazı hemogram belirteçlerinin ROC analizi yapıldı, sensitivite, spesifite ve hemogram belirteçlerinin ortalamaları istatiksel olarak karşılaşıııımada apendektomi sonrasındaki histopatolojisinde inflamasyon bulguları olan ve inflamasyon bulgusu olmayan hasta grupları olarak kullanıldı. Çalışma için Harran Üniversitesi Klinik Araştırmalar Etik Kurulu'ndan etik onam alınmıştır (14/09/2020 tarih, 16 nolu oturum 01 sayilı kurul kararı).

\section{İstatiksel Analiz}

Sürekli sayısal değişkenlerin dağılımının normale yakın dağılıp dağılmadığı Kolmogorov-Smirnov testiyle incelenirken varyansların homojenliği varsayımının sağlanıp sağlanmadığı Levene testiyle araştıııldı. Tanımlayıcı istatistikler; sürekli sayısal değişkenler için ortalama \pm standart sapma veya medyan (1.çeyrek - 3.çeyrek) biçiminde ifade edilirken kategorik değişkenler olgu sayısı ve (\%) şeklinde gösterildi.

Yapılan uyum iyiliği testleri sonucunda parametrik test istatistiği varsayımlarının sağlandığı sürekli sayısal değişkenler yönünden farkların önemliliği bağımsız grup sayısı iki olduğunda Student's t testi ile ikiden fazla bağımsı grup arasındaki farkların önemliliği ise Tek yönlü varyans analizi (One-Way ANOVA) ile değerlendirildi. Parametrik test istatistiği varsayımlarının sağlanmadığı sürekli sayısal değişkenler yönünden gruplar arasındaki farkların önemliliği bağımsız grup sayısı iki olduğunda Mann Whitney U testi ile ikiden fazla bağımsız grup arasındaki farkların önemliliği ise Kruskal Wallis testiyle incelendi. Tek yönlü varyans analizi veya Kruskal Wallis test istatistiği sonuçlarının önemli bulunması durumunda post-hoc Tukey HSD veya Dunn-Bonferroni testi kullanılarak farka neden olan durumlar tespit edildi.

Patolojik bulgusu olan olgular ile patolojik bulgusu olmayan olguları ayırt etmede laboratuvar ölçümlerinin istatistiksel olarak anlamlı bir belirleyiciliğinin olup olmadığı ROC eğrisi altında kalan alan ve \%95 güven aralıkları hesaplanarak incelendi. Eğri altında kalan alanın önemli bulunduğu durumlarda söz konusu laboratuvar ölçümlerine ait duyarlıık ve seçicilik düzeyleri toplamının maksimuma ulaştı̆ı değer en iyi kesim noktası olarak kabul edildi. Daha sonra en iyi kesim noktasındaki duyarlılık, seçicilik, pozitif ve negatif tahmini değerler ile tanısal doğruluk oranları tespit edildi. Kategorik değişkenler Pearson'un $X^{2}$ veya Süreklilik düzeltmeli $\chi^{2}$ testi ile değerlendirildi. 
Verilerin analizi IBM SPSS Statistics 17.0 (IBM Corporation, Armonk, NY, USA) paket programında yapıldı. $p<0.05$ için sonuçlar istatistiksel olarak anlamlı kabul edildi.

\section{Bulgular}

Çalışmamıza Ocak 2018- Haziran 2020 tarih aralığında apendektomi yapıımış 18 yaş ve altındaki 116 çocuk hastalar dahil edildi. Hasta grubunun yaş ortalaması 12.0(912) olup 70'i (60.3\%) erkek, 46sı (39.7\%) kadın idi. Cerrahi öncesi hastaların; 89 (76.7\%)'una batın USG, 21 (18.1\%)'ine de batın BT, 6 (5.2\%)' sına ise hem batın USG hem de batın BT çekimi yapılmış. Apendektomi sonrası yapılan histopatolojik inceleme sonrası hastaların 13 (11.2\%)'ünde normal apendiks dokusu (Grup A), 82 (70.1\%)'sinde basit inflame apandisit (Grup B), 21 (18.7\%)'inde komplike (flegmenöz, gangrenöz, perfore) AA (Grup C) dokusu olmak üzere 3 gruba ayrıldı (Tablo1). Cerrahi sonrası patoloji sonuçlarına göre normal apendiks dokusu ve akut inflame apandisit dokusu olarak gruplandırllan hastaların hemogram belirteçleri incelendi ve bu belirteçlerin ortalama değerleri Tablo 2' de gösterildi ayrıca bu olguların hemogram parametrelerinin ROC analizi yapıldı ve bu parametrelerin değerleri Tablo 3'te gösterildi.

Tablo 1. Hastaların demografik özellikleri, radyolojik görüntüleme oranı ve grupların dağı̆ımı

\begin{tabular}{|l|l|}
\hline Yaş & $12.0(9.0-15.0)$ \\
\hline Cinsiyet & $\begin{array}{l}\text { Erkek: } 60.3 \%(\mathrm{n}: 70) \\
\text { Kadın: 39.7\% (n:46) }\end{array}$ \\
\hline Sadece USG yapılan hasta sayısı & $76.7 \%(\mathrm{n}: 89)$ \\
\hline Sadece BT yapılan hasta sayısı & $18.1 \%(\mathrm{n}: 21)$ \\
\hline Hem USG hem de BT yapılan hasta sayısı & $5.2 \%(\mathrm{n}: 6)$ \\
\hline Grup A & $11.2 \%(\mathrm{n}: 13)$ \\
\hline Grup B & $79.6 \%(\mathrm{n}: 82)$ \\
\hline Grup C & $18.7 \%(\mathrm{n}: 21)$ \\
\hline USG:Ultrasonografi, BT: Bilgisayarlı Tomografi.
\end{tabular}

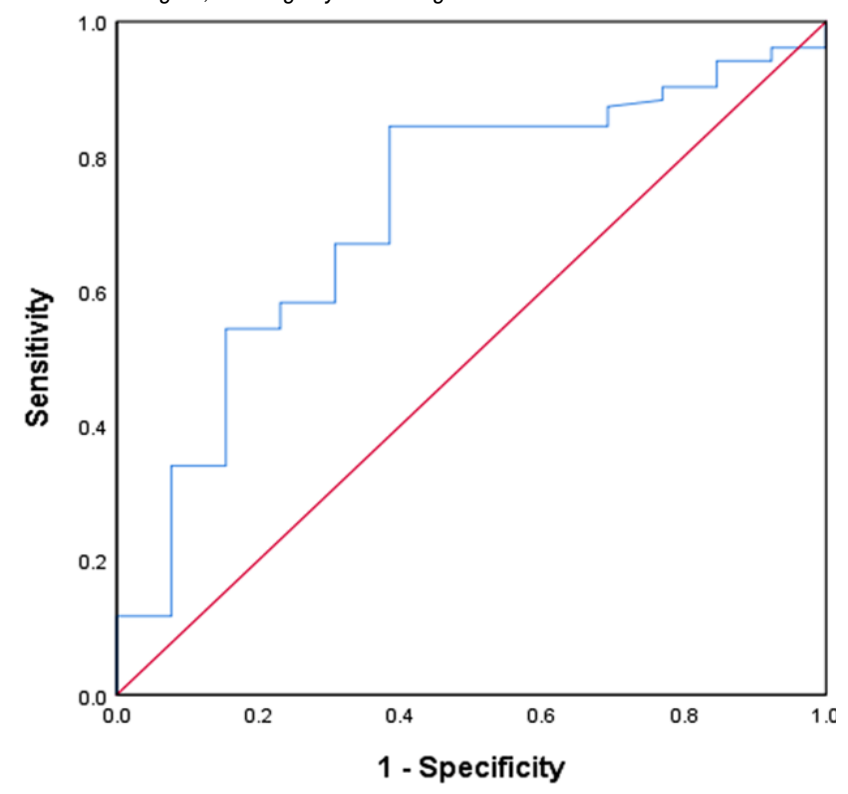

Şekil 1. NLO düzeyinin ROC eğrisi
Tablo 2. Cerrahi sonrası patolojisi normal apendiks dokusu gelen ile apendiks dokusunda inflamasyon bulgularına rastlanan hastaların hemogram parametrelerinin karşıllaştırılması

\begin{tabular}{|l|l|l|l|}
\hline $\begin{array}{l}\text { Hemogram } \\
\text { parametreleri }\end{array}$ & $\begin{array}{l}\text { Normal apendiks } \\
\text { dokusu (n=13) }\end{array}$ & $\begin{array}{l}\text { Akut apandisit } \\
\text { dokusu (AA) (n=103) }\end{array}$ & $\mathrm{p}$ değeri \\
\hline WBC & $11.7 \pm 6.4$ & $14.0 \pm 5.7$ & $\mathrm{p}>0.05$ \\
\hline Nötrofil & $8.3 \pm 5.9$ & $11.1 \pm 5.5$ & $\mathrm{p}>0.05$ \\
\hline Lenfosit & $2.1(1.5-2.6)$ & $1.7(1.1-2.1)$ & $\mathrm{p}>0.05$ \\
\hline Monosit & $0.7(0.6-1.1)$ & $0.8(0.5-1.1)$ & $\mathrm{p}>0.05$ \\
\hline Platelet & $293.0 \quad(238.9-$ & $287.0(246.3-340.7)$ & $\mathrm{p}>0.05$ \\
\hline NLO & $320.1)$ & & $\mathrm{p}<0.05$ \\
\hline LMO & $2.6(1.9-6.1)$ & $7.3(3.6-10.7)$ & $\mathrm{p}>0.05$ \\
\hline MPV & $2.5(1.8-3.1)$ & $1.9(1.4-3.3)$ & $\mathrm{p}>0.05$ \\
\hline RDW & $7.2(6.3-8.4)$ & $7.3(6.4-8.2)$ & $\mathrm{p}>0.05$ \\
\hline PMI & $11.8 \pm 1.7$ & $11.5 \pm 1.5$ & $\mathrm{p}>0.05$ \\
& $1924.8(1720.3-$ & $2092.1(1711.8-2374.5)$ & \\
\hline
\end{tabular}

WBC: Kan beyaz küre sayISI, NLO: nötrofil-lenfosit oranı, LMO: lenfosit-monosit oranı, MPV: Ortalama trombosit hacmi, RDW: Kırmızı kan hücresi genişliği, PMI: Platelet mass index.

Tablo 3. Patoloji bulgusu olan ve olmayan grupları ayırt etmede laboratuvar ölçümlerine ilişkin ROC analizi sonuçları

\begin{tabular}{|l|l|l|l|}
\hline & Eğri altında kalan alan & \%95 Güven Aralı̆̆ı & p değeri \\
\hline WBC & 0.620 & $0.429-0.812$ & 0.159 \\
\hline Nötrofil & 0.644 & $0.460-0.828$ & 0.092 \\
\hline Lenfosit & 0.649 & $0.491-0.808$ & 0.080 \\
\hline Platelet & 0.524 & $0.370-0.678$ & 0.776 \\
\hline NLO & 0.717 & $0.572-0.861$ & 0.011 \\
\hline LMO & 0.588 & $0.453-0.723$ & 0.304 \\
\hline MPV & 0.528 & $0.359-0.696$ & 0.746 \\
\hline RDW & 0.518 & $0.353-0.683$ & 0.830 \\
\hline TKi & 0.545 & $0.371-0.720$ & 0.596 \\
\hline
\end{tabular}

WBC: Kan beyaz küre sayISI, NLO: nötrofil/lenfosit oranı, LMO: lenfosit/monosit oranı, MPV: Ortalama trombosit hacmi, RDW: Kırmızı kan hücresi genişliği, TKi: Trombosit kütle indeksi.

Tablo 4. Patoloji bulgusu normal apendiks dokusu, Basit inflame apandisit dokusu, Komplike (flegmenöz, gangrenöz, perfore) apandisit dokusuna sahip olan grupların laboratuvar ölçümleri

\begin{tabular}{|l|l|l|l|l|}
\hline & $\begin{array}{l}\text { Normal } \\
\text { apendiks do- } \\
\text { kusu (n=13) }\end{array}$ & $\begin{array}{l}\text { Basit inflame } \\
\text { apandisit do- } \\
\text { kusu (n=82) }\end{array}$ & $\begin{array}{l}\text { Komplike (fleg- } \\
\text { menöz, gang- } \\
\text { renöz, perfore) } \\
\text { apandisit do- } \\
\text { kusu (n=21) }\end{array}$ & p-değeri \\
\hline WBC & $11.7 \pm 6.4$ & $13.8 \pm 6.0$ & $14.5 \pm 4.4$ & $P>0.05$ \\
\hline Nötrofil & $8.3 \pm 5.9$ & $10.9 \pm 5.8$ & $11.6 \pm 4.1$ & $P>0.05$ \\
\hline Lenfosit & $2.1(1.5-2.6)$ & $1.7(1.1-2.1)$ & $1.7(1.3-2.1)$ & $\mathrm{P}>0.05$ \\
\hline Monosit & $0.7(0.6-1.1)$ & $0.8(0.4-1.1)$ & $1.0(0.8-1.1)$ & $\mathrm{P}>0.05$ \\
\hline Platelet & 293.0 & 286.2 & 288.9 & $\mathrm{p}>0.05$ \\
\hline NLO & $2.6(1.9-6.1)$ & $7.2(3.3-10.9)$ & $7.8(5.1-9.5)$ & $\mathrm{P}<0.05$ \\
\hline LMO & $2.5(1.8-3.1)$ & $2.0(1.4-3.3)$ & $1.9(1.4-2.4)$ & $\mathrm{P}>0.05$ \\
\hline MPV & $7.2(6.3-8.4)$ & $7.3(6.4-8.2)$ & $7.3(6.5-7.6)$ & $\mathrm{p}>0.05$ \\
\hline RDW & $11.8 \pm 1.7$ & $11.7 \pm 1.5$ & $10.8 \pm 1.3$ & $\mathrm{P}<0.05$ \\
\hline TKI & 1924.8 & 2098.9 & $2083.0(1797.7-$ & $\mathrm{P}>0.05$ \\
& $(1720.3-$ & $(1702.6-$ & $2443.4)$ & \\
\hline
\end{tabular}

WBC: Kan beyaz küre sayısı, NLO: nötrofil/lenfosit oranı, LMO: lenfosit/monosit oranı, MPV: Ortalama trombosit hacmi, RDW: Kırmızı kan hücresi genişliği, TKI: Trombosit kütle indeksi.

Şekil 1'de nötrofil/lenfosit oranına (NLO) ilişkin ROC eğrisi altında kalan alan 0.717 olarak (\%95 Güven Aralığı: 0.5720.861) saptandı ( $p=0.011)$ Patoloji bulgusu olan grup ile patoloji bulgusu olmayan grubu ayırt etmede NLO'na ait en iyi kesim noktası ise 2,75 olarak tespit edildi. NLO'nın bu 
noktadaki sensitivitesi $84.5 \%$, spesifisitesi $61.5 \%$ iken negatif ve pozitif tahmini değerler sırasılya; $33.3 \%$ ve $94.6 \%$ idi. Tanısal doğruluk oranı ise $81.9 \%$ olarak tespit edildi. AA nedeniyle apendektomi yapılan hastaların cerrahi sonrası histopatolojisi normal apendiks dokusu olan, apendiks dokusunda basit inflamasyon ve komplike (flegmenöz, gangrenöz, perfore) apandisit dokusu bulgularına rastlanan hastaların hemogram belirteçleri karşılaştıııldı (Tablo 4).

Histopatolojik bulgusu inflame apandisit dokusu olan hasta grupları ile normal apendiks dokusu içeren gruba göre NLO düzeyinin yüksek olup istatistiksel olarak anlamlı olduğu $(p<0,05)$, komplike (flegmenöz, gangrenöz, perfore) apandisit dokusu içeren grupta ise kırmızı kan hücresi genişliği (RDW) düzeyinin basit inflame apandisit dokusu içeren gruba göre düşük olup istatistiksel olarak anlamlı olduğu $(p<0,05)$ görüldü. Cinsiyet, yaş ve diğer laboratuvar ölçümleri yönünden istatistiksel olarak anlamlı bir bulguya rastlanmadı ( $p>0.05)$.

\section{Tartışma}

AA, birçok etiyolojik sebepleri olmasına rağmen genellikle apendiks lümeninin obstrüksiyonu sonucunda apendiks vermiformisin inflamasyonu ile karakterize cerrahi bir patolojidir (11). Tipik karın ağrısı tablosunun oturmadığı atipik semptomlarla acil servise başvuran hastalarda acil servisin yoğun olması nedeniyle bazen akut apandisit tanısının atlanmasına neden olmaktadır. Son zamanlarda bazı hastalıkların erken tanı ve tedavilerinin takibinde kullanılmak üzere maliyeti düşük, kolay ulaşılabilir biyobelirteçlerin araştırıması ilgi odağı haline gelmiştir. Karın ağrısı şikayetiyle acil servise başvuran bazı hastalarda tanıdaki gecikmelere bağı olarak görülebilen morbidite ve mortalite oranındaki artışlar sebebiyle hastalığın erken tanınmasında kullanılabilecek bazı biyokimyasal belirteçler bulunmaktadır, tam kan sayımı bu biyokimyasal belirteç tanı testleri arasında en hızlı ve kolay ulaşılabilinenidir. Tam kan sayımında; lenfosit, nötrofil, lökosit, NLO, RDW gibi birbirine bağımlı inflamatuvar biyobelirteçler çalışıımıştır (12). Son zamanlarda bu belirteçler için farklı eşik değerlerin sensivite, spesifitesi ve uygun eşik değerlerin tespiti ile ilgili çaışmalar yapılmıştır (13). AA tüm yaş grubunda görülebilmekle beraber özellikle 10 ve 19 yaş arasında daha sık görülmektedir (12). Çalışmamız 18 yaş altı 116 apendektomi yapılmış hasta grubundan seçilmiştir. Türkiye'de yapılmış birkaç çalışmada negatif laparatomi oranları; sevim ve arkadaşları \%17,4, gökçe ve arkadaşları \%17,9 olarak görülmüş olup bizim çalışmamızda ise bu oran $\% 11,2$ olarak tespit edilmiştir fakat literatürde genel olarak bu oranın \%20-30 arasında olduğu kabul edilmektedir $(14,15)$. Beyaz kan hücresi (WBC), nötrofil, MPV, NLO ve kırmızı kan hücre genişliği (RDW) gibi bazı inflamatuvar biyobelirteçler bazı hastalıklarda tanı değerlerinin yüksek olduğu görül- müştür $(16,17)$. Akut apandisit (AA) tanısında bazı inflamatuvar biyobelirteçler ile ilgili çalışmalar yapılmıştır. Son zamanlarda tam kan biyo-belirteçlerinden WBC, nötrofil, MPV, NLO, Kırmızı kan hücre genişliği (RDW) ve Trombosit/Lenfosit oranı (PLO), C-reaktif protein (CRP) değerlerinin akut apandisit tanısında apandisit çapı ile korelasyonuna bakılmıs NLO'nın apandisit çapının 6mm'den daha fazla olduğu apandisit hastalarının tanısında diğerlerinden daha önemli bir biyobelirteç olduğu, yapılan başka bir çaIışmada ise NLO'nın tek başına basit inflame apandisit ile komplike apandisitin ayırt edilmesinde nötrofil, lökosit ve C-reaktif protein (CRP)'den daha iyi bir biyobelirteç olabileceği gösterilmiştir $(4,12)$. Bizim çalışmamızda bu literatür bilgisini desteklemekte olup NLO'nın Patoloji bulgusu inflame apandisit dokusu ile normal apendiks dokusu içeren gruba göre NLO düzeyinin yüksek olup istatistiksel olarak anlamlı düzeyde olduğu görüldü $(p<0.05)$. WBC, nötrofil sayısı, lenfosit, monosit, Lenfosit/Monosit oranı (LMO), ile aralarında istatistiksel olarak anlamlı fark bulunmadı. Ayrıca yaptığımız çalışmada eğri altında kalan ve en uygun eşik değeri için biyobelirteçlerin oranları ROC eğri analizine göre hesaplandı (Tablo 3). Acar ve ark. yapmış oldukları bir çalışmada NLO için 3.3, Kapcı ve ark. ise NLO için en uygun eşik değerin 3.9 olduğu gösterilmiştir $(13,18)$. Bizim çalışmamızda ise NLO için en uygun eşik değer 2,75 olarak tespit edildi. Ortaya çıkan sensitivite ve spesifite oranlarının birbirine yakın olmaması, çalışmaya alınan hasta sayısı ve hasta popülasyonunun demografik özelliklerinden kaynaklandığı düşünülmektedir. Tespit edilen bu değerlerin pratikte kullanımı; yüksek spesifiteye sahip bir cut-off değeri varsa hasta için yakın gözlem sağlayabilirken, yüksek sensitiviteye sahip bir cut-off değerinin üstündeki bir değer olması durumunda ise hastaya ileri tetkikin yanı sıra cerrahi konsültasyon düşünülebilir (13).

MPV, trombosit sayısı ile yorumlandığında trombosit fonksiyonu hakkında daha kesin sonuca ulaşılabilir. Çalışmamızın amaçlarından biri de MPV ile Trombosit sayısının çarpımı sonucu hesaplanan TKI'nin AA'in histopatolojik tanısındaki yerini araştırmak idi (10). MPV trombosit fonksiyonu, aktivasyonu ile ilişkili olduğu ve çeşitli inflamatuar durumlardan etkilendiği bilinmektedir(19). Son çalışmalar MPV'nin de inflamatuar hastalıklarla ilişkili olduğunu göstermiştir (20). Trombositter; dolaşımda bulunan, yara iyileşmesi, tromboz, hemostaz ve enflamasyonda önemli rol oynayan hücrelerdir (21). Yapılan son çalışmalarda Trombositlerin inflamasyondaki rolünün, trombosit aktivasyonu ile inflamasyonlu hastalıkların patofizyolojisi ile arasındaki ilişkinin tespit edilmiştir. Trombosit aktivitesinin ve fonksiyonunun trombosit boyutu ile ilişkili olduğu ve genellikle daha büyük trombositlerin daha genç ve daha reaktif olduğu kabul edilmektedir $(22,23)$. MPV'nin inflamatuar bölgelerdeki büyük ve aktif trombositlerin artan sekestrasyonu ve imha edilmesinden sonra periferik kandaki küçük trombositlerin 
baskın olması nedeniyle yüksek dereceli inflamatuar durumlarında düzeyinin azaldığı bildirilmiştir (14). Haghi ve ark. yapmış olduğu bir çalışmada özellikle yetişkinlerde MPV'nin değerinin gereksiz apendektomiyi azaltmak için kullanılabilineceğini, Daldal ve ark. yapmış olduğu bir çaışmada ise patolojik sonuçları akut apandisit olan hastalarda yüksek MPV'nin değerlerinin görüldüğü bildirilmiş (5, 12). Uyanık ve ark. yapmış olduğu bir çalışmada ise MPV'nin özellikle çocuk akut apandisit olgularında tanısal değerinin olmadığını söylemişler (24). Bizim çalışmamızdaki veriler de uyanık ve arkadaşlarını desteklemektedir ve histopatoloji raporu normal apendiks dokusu olan ile inflame apandisit dokusu olan hastalar arasında MPV'nin ve Trombosit değerlerinin istatistiksel olarak anlamlı olmadığı görülmüştür ( $p>0.05)$. Kan sayımında baktığımız yeni bir parametre olabileceğini düşündüğümüz TKİ değerlerinin histopatolojisi normal apendiks dokusu olan hasta grubunda ortalama 1924.8 (1720.3-2560.4), akut apandisit dokusu olan hasta grubunda ise ortalama 2092.1 (1711.82374.5) değerlerinde olduğu ve iki grup arasında istatistiksel olarak anlamlı olmadığı ( $p>0.05$ ) görülmüş.

Sonuç olarak WBC, nötrofil sayıSI, MPV'nin, NLO, Nötrofil/Monosit oranı, RDW, TKI, gibi parametreler akut AA tanısında kullanılabilen kolay ulaşılabilir ve hızlı bir yöntemdir ancak bu parametrelerin AA tanısını koymakta tek başına yeterli değildir.

Etik onam: Çalışmanın yapılması ile ilgili etik kurul onayı Harran Üniversitesi Tıp Fakültesi Klinik Araştırmalar Etik Kurulu'ndan alınmıştır (14/09/2020 tarih, 16 nolu oturum 01 sayılı kurul kararı).

\section{Kaynaklar}

1. Demircan A, Aygencel G, Karamercan M, Ergin M, Yilmaz TU, Karamercan A. Ultrasonographic findings and evaluation of white blood cell counts in patients undergoing laparotomy with the diagnosis of acute appendicitis. Ulus Travma ve Acil Cerrahi Derg. 2010;16:248-52.

2. Petroianu A. Diagnosis of acute appendicitis. International Journal of Surgery. 2012;10:115-9.

3. Menteş Ö, Eryılmaz M, Yiğit T, Tascı S., Balkan M. KO, Ark. V. 60 yaş üstü apandektomili olgularımızın retrospektif analizi. JAEM. 2008;:36-41.

4. Prasetya D, Rochadi, Gunadi. Accuracy of neutrophil lymphocyte ratio for diagnosis of acute appendicitis in children: A diagnostic study. Ann Med Surg. 2019;48:35-8.

5. Haghi AR, Pourmohammad P, Rabiee MAS. Accuracy of Mean Platelet Volume (MPV) and Red Cell Distribution Width (RDW) for the Diagnosis of Acute Appendicitis: Evaluation of Possible New Biomarkers. Adv J Emerg Med. 2019;4:e20.

6. Gür HÜ, Görmüş C, Çıtlak G, Yüksel S, Ferlengez E, Erözgen F. The place of ultrasonography and alvarado scoring system in the diagnosis of acute appendicitis. Haseki Tip Bul. 2019;57:135-41.

7. Wang LT, Prentiss KA, Simon JZ, Doody DP, Ryan DP. The use of white blood cell count and left shift in the diagnosis of appendicitis in children. Pediatr Emerg Care. 2007;23:69-76.

8. Yang HR, Wang YC, Chung PK, Chen WK, Jeng L Bin, Chen RJ. Laboratory tests in patients with acute appendicitis. ANZ Journal of Surgery. 2006;76:71-4.

9. Narci H, Turk E, Karagulle E, Togan T, Karabulut $K$. The role of red cell distribution width in the diagnosis of acute appendicitis: A retrospective case-controlled study. World J Emerg Surg. 2013;8.

10. May JE, Marques MB, Reddy VVB, Gangaraju R. Three neglected numbers in the CBC: The RDW, MPV, and NRBC count. Cleveland Clinic Journal of Medicine. 2019;86:167-72.

11. Sevim Y, Namdaroglu OB, Akpinar MY, Ertem AG. The diagnostic value of Neutrophil Lymphocyte ratio in acute appendicitis. Sak Med J. 2014;4:78-81.

12. Daldal E, Dagmura H. The Correlation between Complete Blood Count Parameters and Appendix Diameter for the Diagnosis of Acute Appendicitis. Healthcare. 2020;8:39.

13. Kapçı M, Türkdoğan KA, Duman A, Avcil M, Gülen B, Küçükdağlı ÖT, et al. Biomarkers in the diagnosis of acute appendicitis. J Clin Exp Investig. 2014;5:250-5.

14. Boshnak N, Boshnaq M, Elgohary H. Evaluation of Platelet Indices and Red Cell Distribution Width as New Biomarkers for the Diagnosis of Acute Appendicitis. J Investig Surg. 2018;31:121-9.

15. Çınar H, Aygün A, Derebey M, Tarım IA, Akalın, Büyükakıncak S, et al. Significance of hemogram on diagnosis of acute appendicitis during pregnancy. Ulus Travma ve Acil Cerrahi Derg. 2018;24:423-8.

16. Erdim I, Erdur O, Oghan F, Mete F, Celik M. Blood count values and ratios for predicting sleep apnea in obese children. Int J Pediatr Otorhinolaryngol. 2017;98:85-90.

17. Yilmaz E, Bayram Kacar A, Bozpolat A, Zararsiz G, Gorkem BS, Karakukcu $M$, et al. The relationship between hematological parameters and prognosis of children with acute ischemic stroke. Child's Nerv Syst. 2018;34:655-61.

18. Acar E, Özcan Ö, Deliktaş H, Beydilli H, Kırlı İ, Doğan Alataş Ö, et al. Laboratory markers has many valuable parameters in the discrimination between acute appendicitis and renal colic. Ulus Travma Acil Cerrahi Derg. 2016;22:17-22.

19. Ilhan O, Bor M. Platelet mass index and prediction of severity of transient tachypnea of the newborn. Pediatr Int. 2019;61:697-705.

20. Karagöz E, Tanoglu A. Red Blood cell distribution width: an emerging diagnostic factor of acute appendicitis? World J Emerg Surg. 2013;8.

21. Nowak M, Kornhuber J, Meyrer R. Daytime impairment and neurodegeneration in OSAS. Sleep. 2006;29:1521-30.

22. Thachil J. Platelets in Inflammatory Disorders: A Pathophysiological and Clinical Perspective. Seminars in Thrombosis and Hemostasis. 2015;41:572-81.

23. Vagdatli E, Gounari E, Lazaridou E, Katsibourlia E, Tsikopoulou F, Labrianou I. Platelet distribution width: A simple, practical and specific marker of activation of coagulation. Hippokratia. 2010;14:28-32.

24. Uyanik B, Kavalci C, Arslan ED, Yilmaz F, Aslan O, Dede S, et al. Role of Mean Platelet Volume in Diagnosis of Childhood Acute Appendicitis. Emerg Med Int. 2012;2012:1-4. 